\title{
AN ERROR ANALYSIS: PROBLEM SOLVING OF THE MAXIMUM AND MINIMUM DERIVATIVE VALUES WITH NEWMAN'S ERROR ANALYSIS
}

\author{
Terri Murizki Anugrah ${ }^{*}$, Tri Atmojo Kusmayadi ${ }^{2}$ \\ 1SMA Plus Bahrul Ulum Sungailiat, Indonesia \\ ${ }^{2}$ Universitas Sebelas Maret, Indonesia \\ *Email: terrimurizki@gmail.com
}

\begin{abstract}
Abstrak: Penelitian ini bertujuan untuk mendeskripsikan kesalahan yang dilakukan siswa dalam menyelesaikan tes pemecahan masalah nilai turunan maksimum dan minimum. Metode penelitian yang digunakan adalah metode kualitatif deskriptif. Subjek penelitian adalah lima siswa kelas XI SMA di Puding Besar yang dipilih secara purposive sampling. Instrumen yang digunakan dalam penelitian ini adalah tes pemecahan masalah derivatif dan wawancara. Hasil jawaban siswa dianalisis menggunakan analisis kesalahan Newman. Berdasarkan hasil analisis, kesalahan yang paling sering dilakukan siswa adalah kesalahan dalam pemahaman. Sebagian besar siswa kurang memahami konsep pemecahan masalah nilai turunan maksimum dan minimum. Siswa hanya mengerjakan soal aljabar tanpa menggunakan konsep nilai turunan maksimum dan minimum.
\end{abstract}

\section{Kata kunci : Analisis kesalahan, Newman, Pemecahan masalah}

\begin{abstract}
This study aimed to describe the errors made by students in solving of maximum and minimum derivative values problem-solving test. The research method used is the descriptive qualitative method. The subjects consisted of five twelfth grade students of senior high school in Puding Besar who were selected by purposive sampling. The instrument used in this study are derivative problem-solving test and interviews. The results of student answers were analyzed using the Newman's error analysis. Based on the results of the analysis, the most common error made by students were errors in the comprehension errors. The most students do not understand the concept of solving the problems of maximum and minimum derivative values. Students only work on algebraic questions without using concepts of maximum and minimum derivative values.
\end{abstract}

Keywords : Error analysis, Newman, Problem solving

\section{INTRODUCTION}

Living humans will never be separated from various problems. Mathematics teaches ways of thinking in solving problems experienced in life. Even in the 2013 curriculum, mathematics learning in schools began learning by giving problems first. Problem-solving is an attempt to find a way out of difficulties, achieving goals that cannot be immediately achieved and closely related to the processes of mistakes, thinking, learning, memory, transfer, perception, and motivation (Rohmah \& Sutiarso, 2018). Problem-solving is not merely a form of being able to apply rules that have been mastered through past 
learning activities, but more than that is the process of getting a set of rules at a higher level (Hasbullah \& Wibawa, 2017). Mathematical problem solving is a chained task, with each phase dependent upon successful completion of the previous step for correct execution and ultimate arrival at a correct answer (Spooner, et.al., 2017).

Students' ability to solve mathematical problems in Indonesia is still very low. This is indicated by the low average of the national mathematics test scores in the last 3 years experienced by students at Senior High School 1 Puding Besar as in Table 1 below.

Table 1. National Examination Result of Indonesia Senior High School for Last Three Years in Science Class

\begin{tabular}{ccc}
\hline Years & Total Students & Result \\
\hline $2015 / 2016$ & 81 & 22.78 \\
\hline $2016 / 2017$ & 91 & 28.96 \\
\hline $2017 / 2018$ & 93 & 27.40 \\
\hline
\end{tabular}

One of the abilities with the lowest value is the ability to solve problems related to maximum and minimum values using the concept of derivatives. The percentage of ability to solve the problem of the maximum and minimum derivative values in 2016 is 8.64 in this school, 11.66 at the city / district level, 13.31 at the provincial level, and 25.68 at the national level (Kemdikbud, 2016).

Problems related to maximum and minimum values related to application problems on derivatives. The conditions stated maximum and minimum values that are supposed $f$ is a continuous value function and has the first and second derivatives on $x_{1} \in I$ so that:

1. If $f^{\prime}\left(x_{1}\right)=0$ then the point $\left(x_{1}, f\left(x_{1}\right)\right)$ is called stationary / critical.

2. If $f^{\prime}\left(x_{1}\right)=0$ and $f^{\prime \prime}\left(x_{1}\right)>0$ then the point $\left(x_{1}, f\left(x_{1}\right)\right)$ is called the minimum function point.

3. If $f^{\prime}\left(x_{1}\right)=0$ and $f^{\prime \prime}\left(x_{1}\right)<0$ then the point $\left(x_{1}, f\left(x_{1}\right)\right)$ is called the maximum point of function.

4. If $f^{\prime \prime}\left(x_{1}\right)=0$ then the point $\left(x_{1}, f\left(x_{1}\right)\right)$ is called the turning point.

The low student achievement of the ability to solve this problem reveals many errors made by students. Errors are expressions that are contrary to general statements and mathematical definitions and to a generally accepted mathematical-theoretical approach (Heinze, 2004). Errors can occur at any time, therefore, it is necessary to do an error analysis to avoid the cause of an error (White, 2005). Errors made by students can tell the teacher about the progress of students and what remains to be learned for students. In addition, errors are also important for students because errors can be seen as a tool used by students to learn (Nair \& Hui, 2018).

Teachers must not only be aware of students' errors but must also identify, interpret and classify them and must decide whether the errors are relevant enough to be dealt with broadly in front of the 
whole group or individually, and whether errors are caused by underlying misunderstandings (Pankow, et.al., 2018). Mathematical errors students need to get attention because if not addressed immediately, then the error will have an impact on one line to the next math problem (Samule, Amin, \& Fuad, 2017).

Conducting the error analysis when interpreting the results of this achievement test allows examiners to identify specific types and potential patterns of errors, to postulate why the errors are made, and to generate specific interventions to address the identified errors (Mather \& Wendling, 2017). Error analysis can help students find their errors and give them possible ways to correct these errors (Rusthon, 2018). One way to analyze student errors in solving problems is to use Newman's Error Analysis or Newman error analysis. Newman in White says when a person is attempted to answer a standard, written, mathematical word problem then that person has to be able to pass over a number of successive letters: Level 1 Reading (or Decoding), 2 Comprehension, 3 Transformation, 4 Process Skills, and 5 Encoding (White, 2010).

Therefore, this study aims to describe the errors made by students when solving problem solving problems of maximum and minimum derivative values. This study wants to know where the errors made by students are and what causes them.

\section{METHODS}

This research is descriptive qualitative research. The researcher describes errors made by students in solving the problem of maximum and minimum derivative values.

\section{Subject of study}

This research was conducted from September to October 2018 at SMA Negeri 1 Puding Besar. The research subjects consisted of 5 class XII students who were selected by purposive sampling.

\section{Subject of instruments}

The instrument used was validated by experts in mathematics. The instrument is used to determine errors made by students in solving problems of maximum and minimum derivative values. This study uses two instruments, namely written test and interview. As for the explanation of the instrument as follows.

\section{Written test}

Written test is used to determine the location of errors made by students in solving problems of maximum and minimum derivative values. The written test is an essay problem solving problem. Esay tests consist of geometry and economic problems.

\section{Interview}

The interview used was a semi-structured interview. Interview guide uses questions according to the Newman error procedure. The interview aims to explore information that has not been obtained to 
strengthen research data. In finding the type of error researchers must use friendly and polite interviews (Suyitno \& Suyitno, 2015).

\section{Processing of data}

The researcher starts the data collection by giving a written test first, then the analysis is then carried out semi-structured interviews. Researchers analyzed errors using Newman's error analysis guidelines. Data validation used in this study is technical triangulation. Data Triangulation is used to check the validity of data from test results and interview results.

\section{RESULT AND DISCUSSION}

First, the researcher gives a problem solving the maximum and minimum derivative values. The problem given is a problem-solving problem that can be analyzed using Newman's error analysis. Researchers in conducting error analysis based on Newman error analysis as in Table. 2 following.

Table 2. Newman's Error Analysis in This Research

\begin{tabular}{ll}
\hline \multicolumn{1}{c}{ Type of Error } & \multicolumn{1}{c}{ Indicator } \\
\hline Reading error & $\begin{array}{l}\text { The subject is wrong in reading the question and is unable to retrieve } \\
\text { information from the problem. }\end{array}$ \\
\hline Comprehension error & $\begin{array}{l}\text { The subject does not understand the meaning of the given problem, and is } \\
\text { incorrect in determining the steps taken to solve the problem. }\end{array}$ \\
\hline Transformation error & $\begin{array}{l}\text { The subject is wrong in identifying the operation, or sequence of } \\
\text { operations, which is needed to solve the problem. }\end{array}$ \\
\hline Process skills error & \begin{tabular}{l} 
The subject in operating the calculation correctly and cannot determine the \\
systematic problem solving. \\
\hline Encoding error
\end{tabular} \\
The subject is wrong in determining the final answer, the subject is wrong \\
in determining the conclusion and unit.
\end{tabular}

After the data collection process in the problem-solving test, the maximum and minimum derivative values obtained by various types of errors in the stage of comprehension error. The errors that students make when working on problem solving problems are the following maximum and minimum derivative values. 
Problem 1. A rectangular garden with circumference $(2 x+24) m$ and width $(8-x) m$. Determine the length of the park so that the maximum garden area!

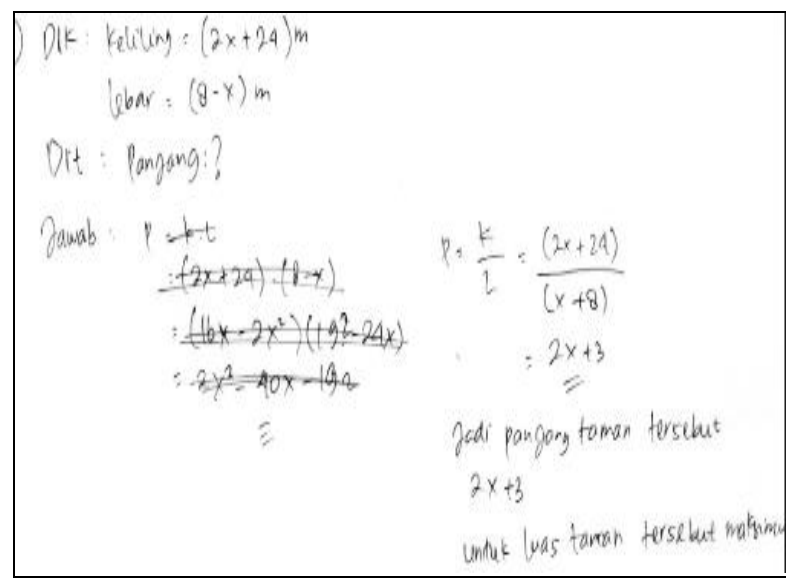

Figure 1. Result of error 1

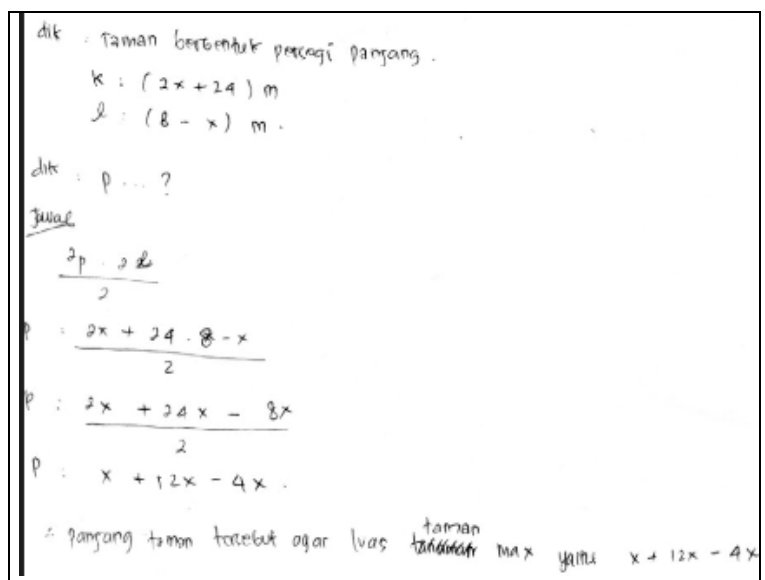

Figure 2. Result of error 2

Based on the results of student answers in Figure 1. Students can take the information contained in the question. This means that students do not experience errors in the reading error stage. In the next step, what steps do students choose when they want to solve this problem. Students show using a long formula, but the formula used is the wrong formula. This reveals that the student's mistake in Figure 1. Occurs in the stage of comprehension error which is wrong using the formula. Students also, in this case, are still weak in using the basic formula of flat plane geometry. Students also at the process skill error stage still experience obstacles in the operation of algebra in the form of fractions. Students' understanding of the derivative concept is not visible. Even though students revealed that they had already received derivative material in class 11 and were recently taught again by a specialization mathematics teacher. This is reinforced by the results of interview researchers on the following research subjects. "R" as researcher and "S" as subject of the research.

$\mathrm{R}$ : what information do you get from the problem?

S: margin equal to $(2 x+24)$ meters and width equals $x+8$ meters.

$\mathrm{R}$ : what was asked from the question?

S: garden length for maximum area sir.

R: what steps will you take next?

$\mathrm{S}$ : determine the length with the circumference formula divided by width.

The results of the interview show that students experience errors when determining the length formula. Because students are only at the stage of comprehension error, which is misunderstanding the purpose of the problem, students also experience errors in transformation errors, process skill errors, and encoding errors. 
The results of the answer in Figure 2 show things that are not much different from errors 1. Students are able to take information from the questions given, but students are also wrong in determining the formula in solving the problem. Students using the formula around the same as $2 p .2 l$ divided by 2 . This means that students experience errors in the stage of comprehension error. The errors identified are caused by students not yet understanding the concept of the maximum and minimum derivative values, still weak in the basic formulas of flat geometry, still constrained by algebraic operations so that they are unable to complete algebraic results to simpler results. This is confirmed by the results of interviews, students claimed to forget the formula around the rectangle. This result is so important for the teacher to know that students in class XII forget the basic formulas, even though soon students will face national examinations.

Problem 2. The cost of producing all goods of a company is expressed in the function $f(x)=8 x^{2}-$ 120x. Then, the selling price of each item is expressed in $f(x)=\frac{1}{3} x^{2}-10 x+200$. If the number of items is expressed by $x$, then how many items are produced to achieve maximum profit?

$$
\begin{aligned}
& \text { Dik: } F(x)=8 x^{2}-120 x \\
& F(x)=\frac{1}{3} x^{2}-10 x+200 \\
& \text { Dit: Jumlah barang yang diprodukst? } \\
& \text { Jwb: } F(x)=8 x^{2}-120 x \\
& \quad f(x)=\frac{1}{3} x^{2}-10 x+200 \\
& 8 x^{2}-120 x \quad|x| \frac{8 x^{2}-120 x}{\frac{1}{3} x^{2}-10 x+200 \mid x 2} \frac{\frac{2}{3} x^{2}-20 x+400}{4-100 x+900} \\
& x=4-100 x+400
\end{aligned}
$$

Figure 3. Result of error 3

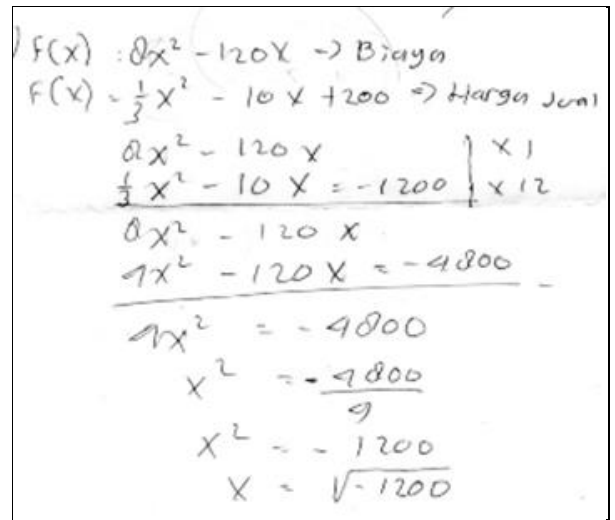

Figure 4. Result of error 4

In the results of Figure 3 above, students do not experience errors in the reading error stage, students are able to write what is known and asked correctly. However, in the next stage student is wrong in determining what steps are used in solving the problem, this means that student has experienced errors in the stage of comprehension error. Students use the method of eliminating both functions. Calculations carried out by student also experienced errors so that student experienced an error during the transformation error stage, the skill error process and student did not write down the conclusions. This is confirmed by the results of interviews with researchers with the following Student.

$\mathrm{R}$ : What information do you get from the problem?

S: Production costs, selling prices and each item expressed in the form of $x$.

$\mathrm{R}$ : What is known and asked? 
S: production costs $f(x)=8 x^{2}-120 x$ and the price of goods is expressed in $f(x)=\frac{1}{3} x^{2}-10 x+$ 200 , which is asked about the number of items produced to achieve maximum profit ?

Q: What next step do you take to find that?

S: by eliminating these two $f(x)$.

Based on these two results, it shows valid data that the Student begins to experience errors in the comprehension stage so that the Student will also experience errors at a later stage, namely transformation error, process skill error and encoding error.

Based on the results of the answers in Figure 4. Show that students cannot take complete information. It appears that students do not write statements for each item expressed in the form of $x$. Students only write down costs and selling prices. This means that students experience errors in the reading error stage. Then in the stage of comprehension error, students are wrong in taking steps to resolve. Students use the method of eliminating the two functions. In other words, students use the formula incorrectly. This means that students experience errors during the transformation error stage. This proves that students' prerequisite material in solving problems is still low for example social arithmetic and algebraic operations.

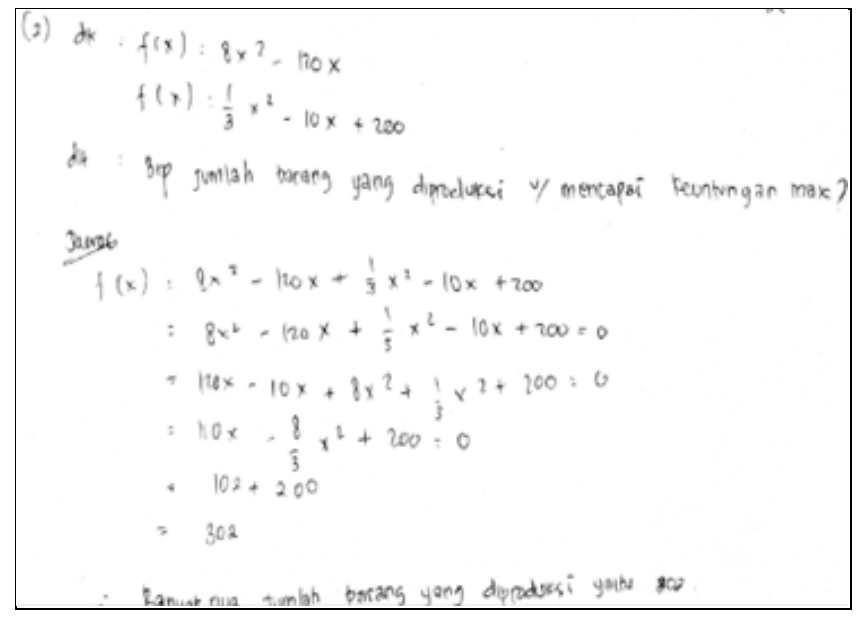

Figure 5. Result of error 5

The same thing happened to the students' answers in Figure 5, but what distinguishes this answer is that students use the sum formula for the two functions. In this case, students also experience the same, namely reading errors, comprehension errors and transformation errors.

Problem 3. From a square-shaped cardboard measuring $18 \mathrm{~cm}$ on the side, a lidless box will be made, by cutting out four squares in each corner of the carton, then folding them along the dotted lines as shown below. 


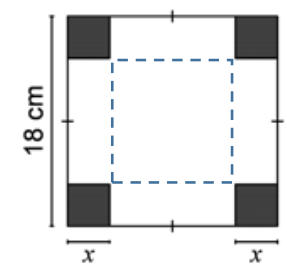

Determine the maximum volume of the box!

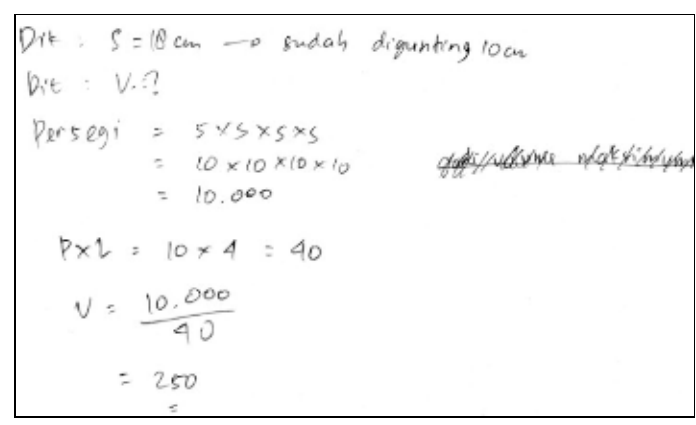

Figure 6. Result of error 6

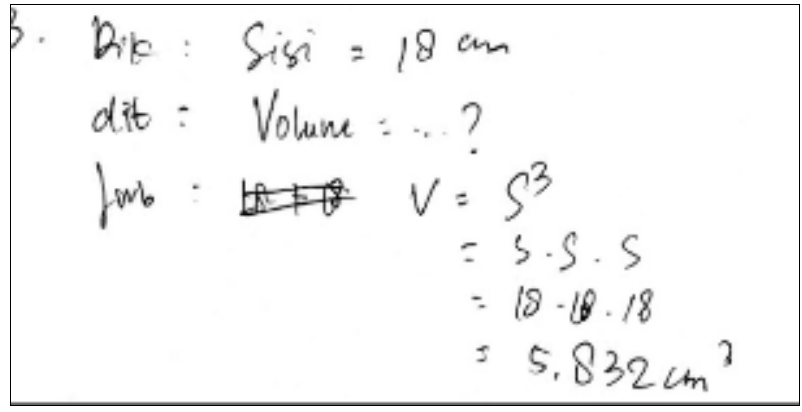

Figure 7. Result of error 7

Based on the answers in Figure 6. It shows that students are still not able to retrieve important information from more complex problem-solving questions. Students only focus on the known side. This means that students experience errors in the reading error stage. In the stage of comprehension error, students are wrong in writing what was asked. Students assume that this is only a matter of finding ordinary volumes. Students consider the sides to be reduced by eight because there are eight areas of the box and students cannot reason when the square is cut following the lines, it will become a beam. Students think that questions are just like ordinary questions that only enter formulas. In the transformation error stage, students are also wrong in using the formula. Students also misread the square formula. The student also writes the volume formula. This results in students being wrong in writing the final answer, meaning that it is wrong at the encoding error stage.

The same is true of students' answers in Figure 7, students also experience errors in reading errors, comprehension errors, transformation errors, and encoding errors. But what is different is that in the students' answers in Figure 7, students use the cube formula. Students assume that a cut square can be transformed into a cube so that it uses the cube volume formula, which is the power side 3 . this is supported by the results of the following interview.

$\mathrm{R}$ : what information do you get from the problem?

$\mathrm{S}$ : square side which is $18 \mathrm{~cm}$, then cut like the one drawn

$\mathrm{R}$ : what was asked?

S: The maximum volume of the box? 
$\mathrm{R}$ : what steps did you take to complete it?

S: use the cube volume formula

$\mathrm{R}$ : why use cube volume?

$\mathrm{S}$ : because the square is cut into cubes?

$\mathrm{R}$ : what is the maximum volume formula with the same usual volume?

S: same sir.

Based on the students' answers in Figures 6 and 7, it appears that students do not use derivative concepts to determine the maximum volume. This was identified as the cause of students errors in answering namely not understanding the derivative concepts in problem-solving questions, students were also still weak in the prerequisite material, namely geometry, building space and students' reasoning in solving problem-solving problems in the picture was still low.

The results of this study reveal that students' ability to solve problem solving problems is still low. It is seen that even students still have difficulty taking important information in more complex questions. Students still do not understand the concept of maximum and minimum derivative values, students are still weak in algebraic operations, and many students even forget basic geometry formulas. In problem 1 students began to experience errors in holding comprehension errors. Then on problems 2 and 3 , which are questions about several levels above, students experience errors in the reading error stage. In other words, students are wrong from the first step in solving the problem. This must be immediately addressed by the teaching mathematics teacher because students of class XII will soon be facing a national examination. Questions like this often appear in the national mathematics exam in the last 3 years.

\section{CONCLUSIONS}

Based on the results of the research and discussion, the researchers concluded that students of class XII Senior High School 1 Puding Besar still made many errors in solving problems of the maximum and minimum values of derivatives. Basic error is made when determining the completion step. In this case it means that students still experience a lot of errors in the stage of comprehension error. This is caused by understanding the derivative concept is still low. Other causes are still weak in the operation of algebra, basic geometry formulas, and social arithmetic problems which are the prerequisites for solving problems. Then the teacher also rarely gets used to starting learning with problem solving problems. This result is expected to provide input for the teacher in preparing class XII students who will face national examinations so that students' solving abilities are better

Vol. 09, No. 1, June 2019 


\section{REFERENCES}

Hasbullah and Wibawa B 2017 Analysis of Mathematics Students Ability in Learning Metacognitive Strategy Type Ideal Identify, Define, Explore, Act, Look IEJME-Mathematics Education 12 859877

Heinze A 2004 Zum Umgang mit Fehlern im Unterrichtsgespräch der Sekundarstufe I Journal für Mathematik-Didaktik, 25 221-244

Kementerian Pendidikan dan Kebudayaan Republik Indonesia 2016 Ujian Nasional Tahun Pelajaran 2015/2016 (Jakarta: BNSP)

Mather N and Wendling B J 2017 Implication of Eror Analysis Studies for Academic Intervention Journal of Psychoeducational Assessment 35 215-225

Nair S M and Hui L L 2018 An Analysis of Common Error In ESL Descriptive Writing Among Chinese Private School Students In Malaysia International Journal of education and Practice 6 28-42

Pankow L, Kaiser G, Konig J and Blomeke S 2018 Perception of Students Errors Under Time Limitation: Are Teacher Faster Than Mathematicans or Students ZIDM 50 631-642

Rohmah M and Sutiarso S 2018 Analysis Problem Solving In Mathematical Using Theory Newman Eurasia Journal of Mathematics, Science and Technology Education 14 671-681

Rushton S J 2018 Teching and Learning Mathematics Through Error Analysis Journal of Cheminformatics 4 1-12

Spooner F, Saunders A, Root J and Brosh C 2017 Promoting Access to Common Core Mathematics for Students with Severe Disabilities Through Mathematical Problem Solving Research and Pratice for Persons with Severe Disabilities 42 171-186

Sumule U, Amin S M and Fuad Y 2017 Error Analysis of Indonesia Junior High School Student in Solving Space and Shape Content PISA Problem Using Newman Procedure Journal of Physics: Conf. Series 947 1-6

Suyitno A and Suyitno, H 2015 Learning Therapy for Students in Mathematics Communication Correctly Based-On Aplication of Newman Procedure (A Case Of Indonesia Student) International Journal of Education and Research 3 529-538

White A L 2005 Active Mathematics in Classrooms: Finding Out Why Children Make Errors Square One 15 (4) pp 15-19

White A L 2010 Numeracy, Literacy and Newman's Analysis Journal of Science and Mathematics 33 $129-148$ 